\title{
Analisis Regresi Logistik Biner pada Faktor-Faktor yang Mempengaruhi Jenis Perceraian di Kabupaten Lumajang
}

\author{
Taufiqotul Masrukha Tesha Nisva dan Vita Ratnasari \\ Departemen Statistika, Fakultas Sains dan Analitika Data \\ Institut Teknologi Sepuluh Nopember (ITS) \\ Jalan Arief Rahman Hakim, Surabaya 60111 Indonesia \\ e-mail: (I)taufiqotul15@mhs.statistika.its.ac.iddan ${ }^{(2)}$ vita_ratna@statistika.its.ac.id
}

\begin{abstract}
Abstrak-Angka perceraian di Jawa Timur cukup mengkhawatirkan karena terjadi kenaikan 4.116 kasus pada tahun 2018 dan menyumbang 21,8\% dari kasus perceraian di Indonesia. Perceraian di Lumajang dalam tiga tahun terakhir terjadi kenaikan jumlah kasus perceraian. Banyak faktor yang mempengaruhi jenis perceraian. Di antaranya ialah usia saat menikah, tingkat pendidikan, lama pernikahan, jenis pekerjaan, dan variabel lainnya. Untuk mengetahui faktor-faktor apa saja yang mempengaruhi jenis perceraian, riset lebih lanjut dapat dilakukan dengan analisis regresi logistik. Terdapat dua jenis perceraian, yakni cerai gugat dan cerai talak. Penelitian ini menggunakan metode regresi logistik biner untuk mengetahui pengaruh tingkat pendidikan, jenis pekerjaan, lama pernikahan, usia saat menikah, dan variabel lainnya terhadap jenis perceraian yang selanjutnya diperoleh pemodelan faktor yang mempengaruhi jenis perceraian. Hasil yang diperoleh adalah bahwa sebanyak 71,8\% kasus cerai di Kabupaten Lumajang merupakan cerai gugat dan sisanya berupa cerai talak. Di Kabupaten Lumajang terdapat kasus pernikahan dini. Variabel yang berpengaruh signifikan terhadap jenis per-ceraian adalah usia pemohon/penggugat dan termohon/tergugat saat menikah, pendidikan pemohon/penggugat, pekerjaan pemohon/penggugat dan termohon/tergugat, keadaan istri saat jatuh talak, dan penyebab perceraian.
\end{abstract}

Kata Kunci-Jenis Perceraian, Regresi Logistik Biner

\section{PENDAHULUAN}

P erceraian adalah penghapusan perkawinan dengan putusan hakim atau tuntutan salah satu pihak dalam perkawinan. Pelaksanaan perceraian harus berdasarkan suatu alasan yang kuat dan merupakan jalan terakhir yang ditempuh oleh suami istri. Perceraian hanya dapat terjadi apabila dilakukan di depan Pengadilan Agama, baik itu karena suami yang menjatuhkan cerai (talak) atau karena istri yang menggugat cerai atau memohon hak talak (cerai gugat).

Jumlah seluruh kasus perceraian yang terjadi di Indonesia tercatat mengalami kenaikan dalam empat tahun terakhir, dimana pada tahun 2018 angka perceraian menyentuh 408.202 kasus. Di Indonesia, provinsi Jawa Timur, Jawa Barat, dan Jawa Tengah secara berturut-turut merupakan tiga wilayah dengan jumlah kasus perceraian terbanyak. Pada tahun 2018, tercatat 88.955 kasus perceraian terjadi di Jawa Timur, diikuti oleh Jawa Barat dengan 87.307 kasus dan Jawa Tengah dengan 75.557 kasus perceraian. Dalam tiga tahun terakhir, angka perceraian di Jawa Timur menyentuh jumlah lebih dari 80 ribu kasus tiap tahunnya. Perkara perceraian di Pengadilan Agama Lumajang cukup memprihatinkan karena dalam tiga tahun terakhir terjadi kenaikan jumlah kasus perceraian. Pada tahun 2016 terdapat 2.654 kasus dan terjadi kenaikan sebanyak 340 kasus pada tahun 2017. Sementara pada tahun 2018, jumlah kasus perceraian menyentuh angka tiga ribu, yakni 3.020 kasus. Sedangkan pada Januari-
Agustus 2019, terjadi kenaikan kasus perceraian sebanyak 313 kasus atau naik sebesar $16 \%$ dibanding tahun 2018 pada rentang bulan yang sama.

Terdapat empat faktor yang memberikan kontribusi terhadap perceraian, yaitu usia saat menikah, tingkat pendapatan, perbedaan perkembangan sosio emosional di antara pasangan, dan sejarah keluarga berkaitan dengan perceraian [1]. Sementara penelitian lain menyebutkan delapan faktor yang mempengaruhi perceraian yakni usia saat menikah, pendidikan, lokasi, ras, pernikahan orang tua, kepemilikan anak, status pekerjaan, dan keuangan. Variabelvariabel tersebut dapat berbentuk variabel kategorik. Salah satu metode untuk mengetahui adanya hubungan antar variabel respon yang bersifat kategorik (nominal atau ordinal) dengan variabel prediktor kontinu maupun kategorik adalah regresi logistik [2], sehingga metode selanjutnya yang digunakan dalam penelitian tugas akhir ini adalah regresi logistik. Karena variabel respon dalam penelitian ini yakni jenis perceraian terdiri atas dua kategori yaitu cerai talak dan cerai gugat, maka digunakan regresi logistik biner.

Permasalahan kasus perceraian di Kabupaten Lumajang yang terus meningkat tiap tahunnya perlu dianalisis lebih lanjut. Sebelum menganalisis lebih lanjut, perlu dilakukan analisis statistika deskriptif terlebih dahulu untuk mengetahui karakteristik faktor-faktor yang terkait dengan jenis perceraian. Kemudian dilakukan analisis regresi logistik biner untuk mendapatkan variabel apa saja yang berpengaruh signifikan terhadap jenis perceraian di Kabupaten Lumajang. Data yang digunakan dalam penelitian ini berasal dari Pengadilan Agama Lumajang, yakni berupa laporan penyebab terjadinya perceraian dan data kasus perceraian pada bulan Agustus 2018 hingga Agustus 2019.

\section{TINJAUAN PUSTAKA}

\section{A. Statistika Deskriptif}

Statistika deskriptif merupakan metode-metode yang berkaitan dengan pengumpulan dan penyajian data sehingga memberikan informasi yang berguna. Metode ini bertujuan untuk menguraikan tentang sifat-sifat atau karakteristik dari suatu keadaan dan membuat gambaran yang sistematis dan akurat mengenai fakta-fakta dan sifat-sifat dari fenomena yang diselidiki. Penyajian data dapat dilakukan dalam bentuk tabel, grafik dan gambar.

\section{B. Tabel Kontingensi}

Tabel kontingensi atau yang sering disebut tabulasi silang adalah tabel yang berisi data jumlah atau frekuensi atau beberapa klasifikasi (kategori). Cross tabulation yaitu suatu metode statistik yang menggambarkan dua atau lebih variabel secara simultan dan hasilnya ditampilkan dalam bentuk tabel 
yang merefleksikan distribusi bersama dua atau lebih variabel dengan jumlah kategori yang terbatas [2]. Metode cross tabulation dapat menjawab hubungan antara dua atau lebih variabel penelitian tetapi bukan hubungan sebab akibat. Semakin bertambah jumlah variabel yang di tabulasikan maka semakin kompleks interpretasinya.

\section{Pengecekan Asumsi Multikolinearitas}

Multikolinieritas terdapat hubungan linier antara beberapa atau semua variabel prediktor pada analisis regresi [3]. Pengecekan asumsi multikolinieritas dapat dilakukan dengan melihat nilai Variance Inflation Factor (VIF) dari setiap variabel prediktor. Jika nilai VIF lebih besar dari 10, mengindikasikan bahwa terjadi adanya kasus multikolinieritas.

\section{Regresi Logistik Biner}

Metode regresi merupakan analisis data yang digunakan untuk mencari hubungan antara variabel respon (y) dengan satu atau lebih variabel prediktor (x) [4]. Tujuan dari metode ini adalah memperoleh model yang baik dan sederhana yang menggambarkan variabel respon dengan sekumpulan variabel prediktor. Regresi logistik merupakan suatu analisis regresi yang digunakan untuk menggambarkan hubungan antara variabel respon yang bersifat dikotomus (berskala nominal atau ordinal dengan dua kategori) atau polikotomus (berskala nominal atau ordinal dengan lebih dari dua kategori) dengan sekumpulan variabel prediktor bersifat kontinu atau kategorik [2]. Berdasarkan skala data pada variabel respon, regresi logistik dapat dibedakan menjadi tiga macam, yaitu regresi logistik biner, regresi logistik ordinal, dan regresi logistik multinomial.

Persamaan regresi logistik yang digunakan dari bentuk tafsiran fungsi peluang $\pi(x)=E(Y \mid x)$ dinyatakan dalam Persamaan (2).

$$
\pi(x)=\frac{e^{\beta_{0}+\beta_{1} x_{1}+\beta_{2} x_{2}+\cdots+\beta_{p} x_{p}}}{1+e^{\beta_{0}+\beta_{1} x_{1}+\beta_{2} x_{2}+\cdots+\beta p x_{p}}}
$$

Kemudian dilakukan transformasi logit untuk menyederhanakan Persamaan (2) dalam bentuk logit sebagai berikut.

$$
g(x)=\ln \left[\frac{\pi(x)}{1-\pi(x)}\right]=\beta_{0}+\beta_{1} x_{1}+\beta_{2} x_{2}+\cdots+\beta_{p} x_{p}
$$

Persamaan (2) merupakan model logit, dimana fungsi tersebut merupakan fungsi linier dari parameterparameternya

Regresi logistik biner merupakan suatu metode statistika yang digunakan untuk pemodelan terbaik yang menggambarkan hubungan antara variabel respon (y) yang bersifat biner atau dikotomus dengan variabel prediktor $(\mathrm{x})$ yang bersifat kualitatif, kuantitatif ataupun kombinasi keduanya [4]. Dalam penelitian ini, variabel respon y terdiri dari 2 kategori yaitu "cerai talak" dan "cerai gugat" yang dinotasikan dengan $\mathrm{y}=1$ (cerai gugat) dan $\mathrm{y}=0$ (cerai talak). Model regresi logistik dengan variabel predictor yaitu $x_{1}, x_{2}, \ldots, x_{p}$ memiliki persamaan seperti Persamaan (1). Transformasi logit $\pi(x)$ yang diperoleh seperti pada Persamaan (2) dilakukan dengan variabel predictor $x=$ $\left(x_{1}, x_{2}, \ldots, x_{p}\right)^{T}$ sehingga diperoleh model regresi logistik seperti pada Persamaan (2), dengan langkah-langkah sebagai berikut.

$$
\begin{aligned}
& \pi(x)\left[1+\exp \left(\beta_{0}+\beta_{1} x_{1}+\beta_{2} x_{2}+\cdots+\beta_{p} x_{p}\right)\right] \\
& =\exp \left(\beta_{0}+\beta_{1} x_{1}+\beta_{2} x_{2}+\cdots+\beta_{p} x_{p}\right) \\
& \begin{aligned}
\pi(x)+\left[\pi ( x ) \operatorname { e x p } \left(\beta_{0}\right.\right. & \left.\left.+\beta_{1} x_{1}+\beta_{2} x_{2}+\cdots+\beta_{p} x_{p}\right)\right] \\
& =\exp \left(\beta_{0}+\beta_{1} x_{1}+\beta_{2} x_{2}+\cdots+\beta_{p} x_{p}\right)
\end{aligned}
\end{aligned}
$$

$$
\begin{aligned}
& \pi(x)=\exp \left(\beta_{0}+\beta_{1} x_{1}+\beta_{2} x_{2}+\cdots+\beta_{p} x_{p}\right)[1-\pi(x)] \\
& \frac{\pi(x)}{1-\pi(x)}=\exp \left(\beta_{0}+\beta_{1} x_{1}+\beta_{2} x_{2}+\cdots+\beta_{p} x_{p}\right) \\
& \ln \left[\frac{\pi(x)}{1-\pi(x)}\right]=\ln \left[\exp \left(\beta_{0}+\beta_{1} x_{1}+\beta_{2} x_{2}+\cdots+\beta_{p} x_{p}\right)\right] \\
& g(x)=\ln \left[\frac{\pi(x)}{1-\pi(x)}\right]=\beta_{0}+\beta_{1} x_{1}+\beta_{2} x_{2}+\cdots+\beta_{p} x_{p}
\end{aligned}
$$

\section{E. Pengujian Parameter}

Pengujian estimasi parameter merupakan pengujian yang digunakan untuk menguji signifikansi koefisien $\beta$ dari model. Pengujian ini dapat menggunakan uji secara parsial maupun serentak.

\section{Uji Serentak}

Hipotesis yang digunakan dalam pengujian ini adalah sebagai berikut.

$\mathrm{H}_{0}: \beta_{1}=\beta_{2}=\ldots=\beta_{\mathrm{p}}=0 \quad$ (variabel prediktor tidak memberikan pengaruh yang signifikan terhadap variabel respon)

$\mathrm{H}_{1}$ : Minimal satu $\beta_{\mathrm{j}} \neq 0$ dengan $\mathrm{j}=1,2, \ldots, \mathrm{p}$ (minimal terdapat satu variabel prediktor memberikan pengaruh yang signifikan terhadap variabel respon).

Statistik uji :

$$
G=-2 \ln \frac{\left[\frac{n_{1}}{n}\right]^{n_{1}}\left[\frac{n_{0}}{n}\right]^{n_{0}}}{\prod_{j=1}^{n} \widehat{\pi}_{j}^{y_{j}}\left[1-\widehat{\pi}_{j}\right]^{1-y_{j}}}
$$

Statistik uji G mengikuti distribusi Chi Square dan jika ditentukan tingkat signifikansi sebesar $\alpha$ dan derajat bebas $p$, maka diputuskan tolak $\mathrm{H}_{0}$ jika nilai $G>\chi_{(a, p)}^{2}$ [4].

\section{Uji Parsial}

Hipotesis yang digunakan dalam pengujian ini adalah sebagai berikut.

$\mathrm{H}_{0} \quad$ : $\beta_{\mathrm{j}}=0$ (variabel prediktor tidak memberikan pengaruh yang signifikan terhadap variabel respon)

$\mathrm{H}_{1} \quad: \quad \beta_{\mathrm{j}} \neq 0$ dengan $\mathrm{j}=1,2, \ldots, \mathrm{p} \quad$ (variabel prediktor memberikan pengaruh yang signifikan terhadap variabel respon).

Statistik uji :

$$
W^{2}=\frac{\widehat{\beta}_{j}{ }^{2}}{\left[\operatorname{SE}\left(\widehat{\beta}_{j}\right)\right]^{2}}
$$

Statistik uji $W^{2}$ mengikuti distribusi Chi-Square dan jika ditentukan tingkat signifikansi sebesar $\alpha$ dan derajat bebas adalah $v$, maka diputuskan tolak $\mathrm{H}_{0}$ jika nilai $W^{2}>\chi_{(a, v)}^{2}$.

\section{F. Interpretasi Model}

Agar memudahkan dalam menginterpretasikan model digunakan nilai odds ratio [4]. Odds ratio diartikan sebagai kecenderungan variabel respon memiliki suatu nilai tertentu jika diberikan $\mathrm{x}=1$ dan dibandingkan pada $\mathrm{x}=0$.

$$
O R=\frac{\pi(1) /[1-\pi(1)]}{\pi(0) /[1-\pi(0)]}
$$

diketahui bahwa $\pi(1)=\frac{\exp \left(\beta_{0}+\beta_{j}\right)}{1+\exp \left(\beta_{0}+\beta_{j}\right)}$ dan $\pi(0)=\frac{\exp \left(\beta_{0}\right)}{1+\exp \left(\beta_{0}\right)}$ dimana $j=1,2, \ldots$, p. Berdasarkan Persamaan (5) maka didapatkan nilai OR sesuai Persamaan (6).

$$
O R=\exp \left(\beta_{j}\right)
$$

Keputusan tidak terdapat hubungan antara variabel prediktor diambil jika nilai odds ratio sama dengan 1. Jika nilai odds ratio kurang dari 1, maka antara variabel prediktor dan variabel respon terdapat hubungan negatif setiap kali perubahan nilai variabel bebas (x). Dan jika odds ratio lebih dari 1 maka antara variabel prediktor dengan variabel respon terdapat hubungan positif setiap kali perubahan nilai variabel bebas $(\mathrm{x})$. 


\section{G. Uji Kesesuaian Model}

Uji kesesuaian model dilakukan dengan tujuan untuk mengetahui apakah tidak ada perbedaan antara hasil observasi dengan kemungkinan hasil prediksi model. Uji kesesuaian model memiliki hipotesis pengujian sebagai berikut.

$\mathrm{H}_{0}$ : Model sesuai (tidak terdapat perbedaan yang signifikan antara hasil observasi dengan kemungkinan prediksi model)

$\mathrm{H}_{1}$ : Model tidak sesuai (terdapat perbedaan yang signifikan antara hasil observasi dengan kemungkinan prediksi model)

$$
\text { Statistik uji: } \hat{C}=\sum_{l=1}^{g} \frac{\left(o_{l}-n_{l}^{\prime} \bar{\pi}_{l}\right)^{2}}{n_{l}^{\prime} \bar{\pi}_{l}\left(1-\bar{\pi}_{l}\right)}
$$

Statistik uji Hosmer Lemeshow mengikuti distribusi ChiSquare dengan derajat bebas $g-2$ dan jika ditentukan tingkat signifikansi sebesar $\alpha$, maka diperoleh keputusan tolak $\mathrm{H}_{0}$ jika nilai $\hat{C}>\chi_{(a, g-2)}^{2}$.

\section{H. Ketepatan Klasifikasi Model}

Ketepatan hasil klasifikasi diperoleh melalui nilai akurasi yang dihasilkan oleh confusion matrix. Variabel respon yang memiliki dua kelas memiliki empat kemungkinan hasil prediksi klasifikasi yang berbeda yaitu true positive (TP), true negative (TN), false positive ( $\mathrm{FP})$, dan false negative ( $\mathrm{FN})$. Berikut adalah confusion matrix dengan dua kelas pada variable respon [5].

Tabel 1

Confusion Matrix

\begin{tabular}{cccc}
\hline \hline & & \multicolumn{3}{c}{ Predicted Membership } \\
\cline { 2 - 4 } & & 1 & 0 \\
\hline Actual & 1 & TP & FN \\
\cline { 2 - 4 } Membership & 0 & FP & TN \\
\hline \hline
\end{tabular}

dimana:

TP : Jumlah dokumen dari kelas 1 yang benar dan diklasifikasikan sebagai kelas 1 .

TN : Jumlah dokumen dari kelas 0 yang benar dan diklasifikasikan sebagai kelas 0 .

FP : Jumlah dokumen dari kelas 0 yang salah dan diklasifikasikan sebagai kelas 1.

FN : Jumlah dokumen dari kelas 1 yang salah dan diklasifikasikan sebagai kelas 0 .

Sehingga, APERnya adalah

$$
\begin{gathered}
\text { Apparent Error Rate }(A P E R)=\frac{T N+T P}{T P+F P+F N+T} \\
\text { Akurasi }=1-\text { APER }
\end{gathered}
$$

Selain itu, Area Under ROC (Receive Operating Chararcteristic) Curve (AUC) juga dapat digunakan untuk menggambarkan probabilitias antara sensitivity dan spesificity dengan batas 0 hingga 1. Jika nilai AUC mendekati 1, maka model klasifikasi yang terbentuk semakin akurat. Nilai AUC dapat dihitung dengan persamaan berikut.

$$
A U C=\frac{1}{2}(\text { sensitivity }+ \text { spesificity })
$$

dengan

$$
\begin{aligned}
& \text { sensitivity }=\frac{T P}{T P+F N} \\
& \text { spesificity }=\frac{T N}{F P+T N}
\end{aligned}
$$

AUC merupakan salah satu kriteria yang dapat digunkaan untuk mengukur kualitas hasil dari metode klasifikasi [6]. AUC adalah area di bawah kurva ROC. Kurva ROC adalah grafik popular untuk menampilkan secara bersamaan kurva dari dua kenis kesalahan untuk semua thereshold yang mungkin. Kurva ROC yang ideal akan melengkung di sudut kiri atas, dimana garis lengkung menunjukkan tingkat true positive yang tinggi dan tingkat false positive yang rendah. Semakin besar area di bawah kurva ROC (AUC), maka semakin baik hasil klasifikasi yang dihasilkan [7]. Kriteria keakuratan klasifikasi menggunakan AUC ditunjukkan Tabel 2.

Tabel 2

Kriteria Nilai AUC

\begin{tabular}{cc}
\hline \hline Nilai AUC & Interpretasi \\
\hline $0,9-1,0$ & Excellent Classification \\
$0,8-0,9$ & Good Classification \\
$0,7-0,8$ & Fair Classification \\
$0,6-0,7$ & Poor Classification \\
$0,5-0,6$ & Failed \\
\hline \hline
\end{tabular}

Pengertian dari sensitivitas adalah proporsi dari kelas 1 yang teridentifikasi dengan benar. Sedangkan spesifitas adalah proporsi dari kelas 0 yang teridentifikasi dengan benar.

\section{Perceraian}

Perceraian merupakan berakhirnya hubungan suami-istri dari suatu perkawinan yang sah yang disebabkan oleh alasan tertentu.

UU Nomor 1 Tahun 1974 tentang Perkawinan mengenal dua jenis gugatan perceraian, diantaranya:

a. Cerai Talak, yaitu sebagaimana pengertian talak dalam hukum islam yakni melepaskan dan meninggalkan suatu ikatan. Talak dijatuhkan oleh suami kepada istri.

b. Cerai Gugat, yaitu suatu gugatan yang diajukan oleh istri terhadap suami kepada pengadilan dengan alasan-alasan tertentu.

Perceraian tidak terjadi karena satu alasan dan terdapat beberapa faktor yang mempengaruhi terjadinya perceraian. Terdapat empat faktor yang memberikan kontribusi terhadap perceraian [1], yaitu usia saat menikah, tingkat pendapatan, perbedaan perkembangan sosio emosional di antara pasangan, dan sejarah keluarga berkaitan dengan perceraian.

\section{METODOLOGI PENELITIAN}

\section{A. Sumber Data}

Data yang digunakan pada penelitian tugas akhir ini merupakan data sekunder berupa data dari register perkara perceraian yang tercatat di Kepaniteraan Pengadilan Agama Lumajang bagian Panitera Muda Hukum tentang Laporan Perkara. Data yang digunakan merupakan perkara perceraian yang terjadi di Kabupaten Lumajang pada Agustus 2018 hingga Agustus 2019 dengan total jumlah perkara 3.491 perkara. Unit sampling berupa perkara perceraian.

\section{B. Variabel Penelitian}

Variabel yang digunakan dalam penelitian ini disajikan pada Tabel 3.

Tabel 3

Variabel Penelitian

\begin{tabular}{clcc}
\hline \hline Variabel & \multicolumn{1}{c}{$\begin{array}{c}\text { Nama } \\
\text { Variabel }\end{array}$} & \multicolumn{1}{c}{ Kategori } & Skala \\
& Jenis & 0: Cerai Gugat & Nominal \\
& perceraian & 1 : Cerai Talak & \\
\hline $\mathrm{X}_{1}$ & Usia & - & Rasio \\
& pemohon/pen & & \\
& $\begin{array}{l}\text { ggugat saat } \\
\text { menikah }\end{array}$ & & \\
& & & \\
\hline
\end{tabular}




\begin{tabular}{|c|c|c|c|}
\hline Variabel & $\begin{array}{c}\text { Nama } \\
\text { Variabel }\end{array}$ & Kategori & Skala \\
\hline $\mathrm{X}_{2}$ & $\begin{array}{l}\text { Usia } \\
\text { termohon/terg } \\
\text { ugat saat } \\
\text { menikah }\end{array}$ & - & Rasio \\
\hline $\mathrm{X}_{3}$ & $\begin{array}{l}\text { Pendidikan } \\
\text { pemohon/pen } \\
\text { ggugat }\end{array}$ & $\begin{array}{l}0: \text { TK dan } \\
\text { SD/sederajat } \\
\text { 1:SMP/sederajat } \\
\text { 2:SMA/sederajat } \\
\text { 3:Perguruan Tinggi }\end{array}$ & Ordinal \\
\hline $\mathrm{X}_{4}$ & $\begin{array}{l}\text { Pendidikan } \\
\text { termohon/terg } \\
\text { ugat }\end{array}$ & $\begin{array}{l}0: \text { TK dan } \\
\text { SD/sederajat } \\
\text { 1:SMP/sederajat } \\
\text { 2:SMA/sederajat } \\
\text { 3:Perguruan Tinggi }\end{array}$ & Ordinal \\
\hline$\overline{X_{5}}$ & $\begin{array}{l}\text { Pekerjaan } \\
\text { pemohon/pen } \\
\text { ggugat }\end{array}$ & $\begin{array}{l}\text { 0:Tidak bekerja } \\
\text { 1:Petani/Peternak/ } \\
\text { Nelayan } \\
\text { 2:ART/TKI/ } \\
\text { Buruh/Kuli/ } \\
\text { Tukang/Supir/Ojek/ } \\
\text { Kernet/Satpam } \\
\text { 3:Karyawan/Sales } \\
\text { 4:Jasa/Pedagang/ } \\
\text { Wirausaha } \\
\text { 5:Guru/Pegawai/ } \\
\text { Pegawai Negeri } \\
\text { Sipil/ TNI/Tenaga } \\
\text { kesehatan/Tenaga } \\
\text { profesional lain } \\
\end{array}$ & Nominal \\
\hline $\mathrm{X}_{6}$ & $\begin{array}{l}\text { Pekerjaan } \\
\text { termohon/terg } \\
\text { ugat }\end{array}$ & $\begin{array}{l}\text { 0:Tidak bekerja } \\
\text { 1:Petani/Peternak/ } \\
\text { Nelayan } \\
\text { 2:ART/TKI/ } \\
\text { Buruh/Kuli/ } \\
\text { Tukang/Supir/Ojek/ } \\
\text { Kernet/Satpam } \\
\text { 3:Karyawan/Sales } \\
\text { 4:Jasa/Pedagang/ } \\
\text { Wirausaha } \\
\text { 5:Guru/Pegawai/ } \\
\text { Pegawai Negeri } \\
\text { Sipil/ TNI/Tenaga } \\
\text { kesehatan/Tenaga } \\
\text { profesional lain } \\
\end{array}$ & Nominal \\
\hline $\mathrm{X}_{7}$ & $\begin{array}{l}\text { Lama } \\
\text { pernikahan }\end{array}$ & - & Rasio \\
\hline $\mathrm{X}_{8}$ & $\begin{array}{l}\text { Keadaan istri } \\
\text { saat jatuh } \\
\text { talak }\end{array}$ & $\begin{array}{l}0: \text { Tidak diketahui } \\
1: \text { Suci } \\
2: \text { Haid }\end{array}$ & Nominal \\
\hline $\mathrm{X}_{9}$ & $\begin{array}{l}\text { Keadaan } \\
\text { perceraian }\end{array}$ & $\begin{array}{l}0: \text { Ba'da Duhul } \\
1: \text { Qobla Duhul }\end{array}$ & Nominal \\
\hline $\mathrm{X}_{10}$ & $\begin{array}{l}\text { Sebab } \\
\text { perceraian }\end{array}$ & - & Nominal \\
\hline
\end{tabular}

\section{Langkah Penelitian}

Langkah-langkah penelitian yang dilakukan adalah sebagai berikut:

1. Mendeskripsikan faktor-faktor yang terkait dengan jenis perceraian di Kabupaten Lumajang.

a. Melakukan analisis statistika deskriptif yaitu crosstab atau tabulasi silang untuk mengetahui karakteristik data faktor yang mempengaruhi perceraian di Kabupaten Lumajang.

b. Melakukan analisis statistika deskriptif berupa bar chart dan pie chart serta pemetaan dengan software Arcview.
2. Memodelkan faktor yang mempengaruhi jenis perceraian di Kabupaten Lumajang dengan menggunakan regresi logistik biner.

a. Melakukan uji asumsi multikolinearitas. Jika terjadi multikolinearitas, diatasi dengan metode seleksi backward elimination dan menghilangkan variabel penyebab multikolinearitas.

b. Memodelkan faktor-faktor yang mempengaruhi jenis perceraian di Kabupaten Lumajang dengan menggunakan analisis regresi logistik biner dengan masing-masing model:

i. Model awal: Melibatkan seluruh variabel tanpa seleksi

ii. Model terbaik: Melibatkan variabel hasil seleksi dengan backward elimination

c. Melakukan uji signifikansi parameter regresi logistik untuk mengetahui model dari semua variabel predictor yang berpengaruh signifikan terhadap variabel respon.

d. Melakukan interpretasi nilai odds ratio yang diperoleh dari model terbaik yang didapatkan dengan analisis regresi logistik.

3. Membandingkan hasil uji kesesuaian model pada masingmasing model untuk mengetahui apakah model telah sesuai.

4. Mengidentifikasi ketepatan klasifikasi sesuai dengan rumus ketepatan klasifikasi, dihitung untuk masingmasing model.

5. Menarik kesimpulan dan saran.

\section{ANALISIS DAN PEMBAHASAN}

\section{A. Karakteristik Data Perceraian di Kabupaten Lumajang}

Sebelum melakukan analisis regresi logistik biner, dilakukan analisis statistika deskriptif untuk mengetahui karakteristik para pihak yang mendaftarkan gugatan perceraian di Pengadilan Agama Kabupaten Lumajang. Berikut merupakan statistika deskriptif untuk variabel yang bersifat rasio, ditunjukkan oleh Tabel 4.

Tabel 4

Statistika Deskriptif Variabel dengan Skala Data Rasio

\begin{tabular}{llllll}
\hline \hline Variabel & Mean & Min & Maks & Modus & $\begin{array}{l}\text { Nfor } \\
\text { Mode }\end{array}$ \\
\hline $\begin{array}{l}\text { Lama } \\
\text { pernikahan }\end{array}$ & 8,9 & 0,2 & 42,7 & 0,6 & 49 \\
\hline $\begin{array}{l}\text { Usia } \\
\text { pemohon/pen } \\
\text { ggugat saat } \\
\text { menikah }\end{array}$ & 23,3 & 12 & 67 & 17 & 343 \\
\hline $\begin{array}{l}\text { Usia } \\
\text { termohon/terg } \\
\text { ugat saat } \\
\text { menikah }\end{array}$ & 25,33 & 12 & 67 & 21 & 306 \\
\hline \hline
\end{tabular}

Tabel 3 menunjukkan bahwa rata-rata lama pernikahan pasangan yang bercerai adalah mendekati 9 tahun. Terdapat pasangan yang pernikahannya hanya berlangsung selama 2,4 bulan, dan lama pernikahan pasangan cerai paling panjang ialah 42 tahun 7 bulan. Modus dari data lama pernikahan adalah 7,2 bulan yakni sebanyak 49 data, menunjukkan banyak pasangan yang memilih bercerai meskipun usia pernikahan belum genap 1 tahun. Rata-rata pemohon/penggugat menikah saat berusia 23 tahun. Sementara itu, rata-rata umur termohon/tergugat saat menikah ialah 25 tahun. Terdapat pemohon/penggugat dan termohon/tergugat yang menikah ketika berumur 12 tahun. Sebanyak 343 atau $9,8 \%$ pemohon/penggugat 
melangsungkan pernikahan ketika berusia 17 tahun, sedangkan 306 atau 8,7\% termohon/tergugat melakukan pernikahan saat berumur 21 tahun.

Di Kabupaten Lumajang, sebanyak 29,5\% atau 1.033 pemohon/penggugat cerai adalah orang yang menikah di bawah usia 19 tahun, sementara $11,8 \%$ atau 412 termohon/tergugat menikah ketika masih di bawah umur 19 tahun. Hal ini menunjukkan bahwa di Kabupaten Lumajang masih terdapat kasus pernikahan dini atau pernikahan di bawah umur. Selain itu, terdapat fakta bahwa orang yang menikah ketika di bawah usia 19 tahun cenderung merupakan pihak pemohon/penggugat atau pihak pengaju cerai.

Tabel 5

Pengelompokan Usia Saat Menikah

\begin{tabular}{cc}
\hline \hline Usia Saat Menikah & Koding \\
\hline $12-19$ tahun & 0 \\
\hline $20-29$ tahun & 1 \\
\hline $30-40$ tahun & 2 \\
\hline$>40$ tahun & 3 \\
\hline \hline
\end{tabular}

Berdasarkan pengelompokan usia saat menikah pada Tabel 5, diketahui bahwa sebanyak 1.145 istri yang mengajukan cerai menikah ketika masih di bawah umur. Sementara sejumlah 28\% lain menikah di antara usia 20 hingga 29 tahun. Seperti halnya untuk cerai talak, diperoleh fakta bahwa suami-suami yang mengajukan cerai lebih banyak menikah ketika umur 20 sampai 29 tahun. Selanjutnya adalah usia termohon/tergugat saat menikah. Diperoleh informasi bahwa suami yang paling banyak digugat cerai adalah suami yang saat menikah berada pada usia antara 20 hingga 29 tahun. Kelompok kedua yang paling banyak digugat cerai adalah suami yang saat menikah berusia pada rentang 30 sampai 40 tahun. Sementara untuk cerai talak, istri yang saat menikah berusia antara 20 hingga 29 tahun adalah istri yang paling banyak ditalak.

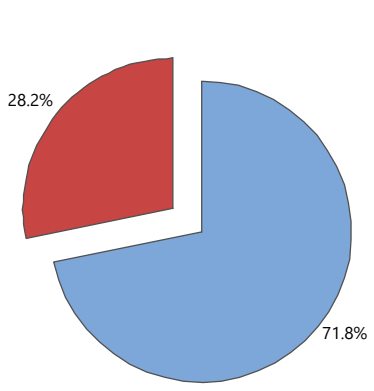

Gambar 1. Persentase Jenis Perceraian di Kabupaten Lumajang

Berikutnya ialah analisis tabel kontingensi lama pernikahan. Didapatkan informasi bahwa untuk cerai gugat atau cerai yang diajukan oleh istri, sebanyak $44,3 \%$ pasangan telah menjalani pernikahan selama rentang waktu 1 hingga 10 tahun. Sedangkan 798 lain telah melalui bahtera rumah tangga selama lebih dari 10 tahun. Begitu pula untuk kasus cerai talak, lama pernikahan pasangan yang bercerai paling banyak berada dalam rentang 1 hingga 10 tahun. Sementara itu, kasus cerai gugat mencatatkan lebih banyak kasus perceraian dengan lama pernikahan di bawah 1 tahun dibandingkan cerai talak

Gambar 1 memperlihatkan bahwa sebesar $71,8 \%$ atau sebanyak 2.506 kasus perceraian di Kabupaten Lumajang merupakan cerai gugat atau cerai yang diajukan oleh istri kepada suami, sedangkan sisanya yakni $28,2 \%$ atau 985 merupakan cerai talak atau cerai yang diajukan suami kepada istri.
Analisis tabel kontingensi untuk tingkat pendidikan pemohon/penggugat memberikan informasi bahwa 4,3\% istri yang mengajukan cerai (cerai gugat) telah berpendidikan setingkat perguruan tinggi, lebih banyak bila dibandingkan dengan persentase suami yang hanya 1,6\% (cerai talak). Hal ini menjelaskan bahwa pihak istri yang mengajukan cerai cenderung memiliki tingkat pendidikan lebih tinggi dibandingkan suami yang mengajukan cerai.
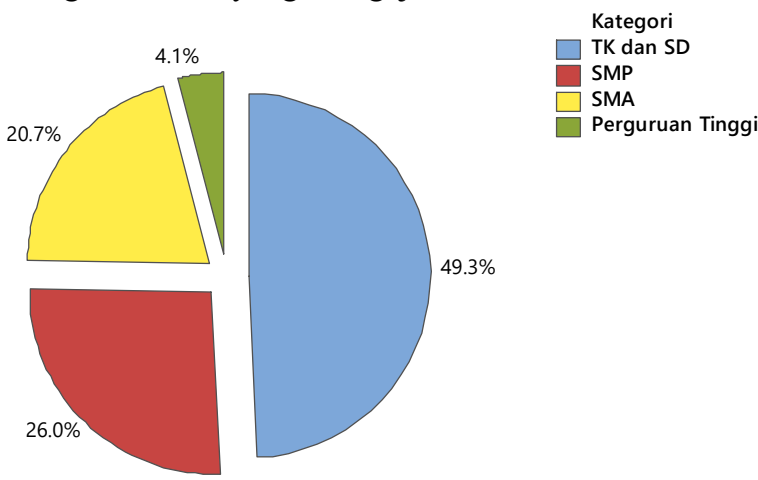

Gambar 2. Persentase Tingkat Pendidikan Termohon/Tergugat

Gambar 2 menunjukkan bahwa 49,3\% atau hampir setengah dari pihak termohon/tergugat hanya menempuh pendidikan setara SD. Jumlah tersebut lebih banyak daripada persentase pendidikan SD untuk pihak pemohon/penggugat. Hanya sebanyak 142 orang atau 4,1\% termohon/tergugat yang menempuh pendidikan hingga tingkat perguruan tinggi, dimana jumlah ini lebih sedikit dibandingkan kategori serupa untuk pihak pemohon/penggugat. Hal ini memberikan informasi bahwa pihak pemohon/penggugat cerai memiliki tingkat pendidikan lebih tinggi daripada pihak termohon/tergugat.

Dari segi pekerjaan, baik untuk pemohon/penggugat maupun termohon/tergugat, status pekerjaan paling banyak adalah Tidak Bekerja. Sebanyak 949 pihak termohon/tergugat tidak memiliki pekerjaan, dimana hal ini lebih banyak jumlahnya bila dibandingkan dengan pihak pemohon/penggugat. Tercatat 816 orang termohon/tergugat bekerja sebagai petani, dimana hal tersebut $18 \%$ lebih banyak dibandingkan pihak pemohon/penggugat. Salah satu fakta mencolok dari perbandingan antara pekerjaan pemohon/penggugat dengan termohon/tergugat adalah jenis pekerjaan asisten rumah tangga (ART). Pada pihak pemohon/penggugat, terdapat 100 orang bekerja sebagai ART, sementara pada pihak termohon/tergugat hanya tercatat 3 orang yang bekerja sebagai ART. Hal tersebut menunjukkan bahwa orang yang bekerja sebagai ART cenderung merupakan pihak yang pemohon/penggugat atau pihak yang mengajukan cerai.

Sebanyak 2733 istri saat jatuh talak sedang berada dalam masa suci atau tidak haid. Sedangkan hanya 6 orang yang berada dalam masa haid ketika jatuh talak. Sementara sisanya yakni 752 orang tidak diketahui keadaannya ketika talak dijatuhkan.

Mayoritas pasangan yang bercerai di Kabupaten Lumajang berada dalam keadaan Qobla Duhul atau bercerai setelah melakukan hubungan suami istri. Meski begitu, terdapat 54 pasangan yang bercerai sebelum melakukan hubungan suami istri.

Selama periode Agustus 2018 hingga Agustus 2019, perceraian di Kabupaten Lumajang mayoritas disebabkan oleh alasan meninggalkan kewajiban, yakni sebanyak 3.280 kasus. Alasan moral menjadi kelompok penyebab perceraian 
terbanyak kedua yakni dengan jumlah 195 kasus atau 5,6\%. Sementara hanya terdapat 16 kasus perceraian yang disebabkan oleh alasan penganiayaan.

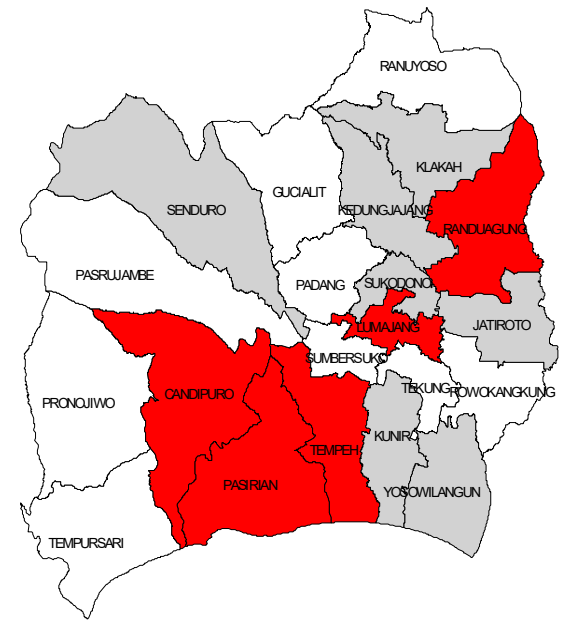

Jumlah Perceraian $75-140$ $140-200$ $200-320$

Gambar 3. Jumlah Perceraian di Kabupaten Lumajang

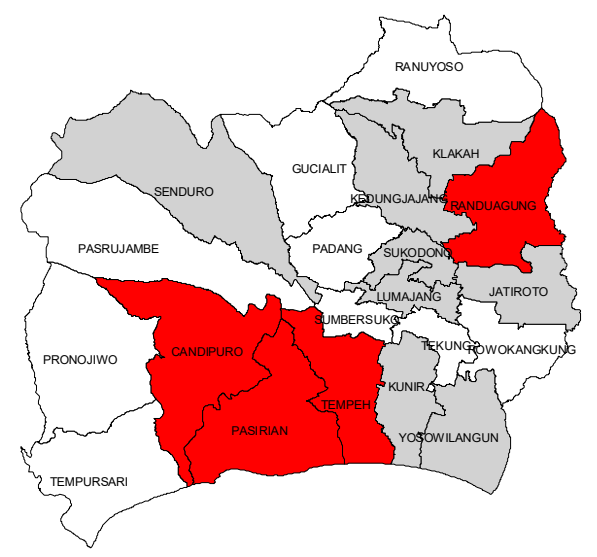

Nikah Dini $35-60$
$60-85$ $85-120$

Gambar 4. Jumlah Pelaku Pernikahan Dini di Kabupaten Lumajang

Berdasarkan Gambar 3 terlihat bahwa pada periode Agustus 2018 hingga Agustus 2019, di 5 kecamatan yakni Kecamatan Lumajang, Randuagung, Tempeh, Candipuro, dan Pasirian terjadi lebih dari 200 kasus perceraian. Untuk kelompok kedua yakni jumlah kasus perceraian dalam interval 140 hingga 200 kasus yakni Kecamatan Klakah, Senduro, Kedungjajang, Sukodono, Jatiroto, Kunir, dan Yosowilangun. Sementara 9 kecamatan lainnya memiliki jumlah kasus perceraian dalam interval 75 hingga 140 kasus. Dari 5 kecamatan dengan jumlah perceraian di atas 200, kecamatan yang memiliki jumlah perkara perceraian paling tinggi adalah Kecamatan Tempeh yakni dengan total 317 kasus perceraian, diikuti Pasirian dengan 277 jumlah perceraian, Candipuro dengan jumlah 250 perkara, Kecamatan Lumajang dengan 245 kasus perceraian, dan Randuagung dengan 211 perkara perceraian. Kecamatan Tempeh adalah satu-satunya kecamatan di Kabupaten Lumajang yang mencatatkan jumlah kasus cerai gugat lebih dari 200 kasus dan cerai talak lebih dari 100 kasus. Jumlah cerai gugat pada masing-masing wilayah terlihat selalu lebih banyak dibandingkan jumlah cerai talak. Kecamatan Randuagung merupakan wilayah dengan persentase cerai gugat tertinggi yakni sebesar 76,78\%, diikuti dengan Kecamatan Lumajang yakni 72,65\%. Sementara untuk cerai talak, Kecamatan Candipuro memiliki persentase tertinggi yakni $34,44 \%$ diikuti Kecamatan Tempeh dengan persentase $33,44 \%$.
Melalui Gambar 4 diketahui bahwa terdapat 4 wilayah dengan jumlah pelaku pernikahan dini lebih dari 85 orang, yakni Kecamatan Candipuro, Kecamatan Randuagung, Pasirian, dan Tempeh. Empat kecamatan tersebut masuk ke dalam kelompok daerah dengan jumlah perceraian paling banyak seperti ditunjukkan pada Gambar 3. Fakta ini menunjukkan bahwa di daerah-daerah dengan jumlah kasus perceraian tertinggi, banyak masyarakatnya yang menikah dini atau menikah ketika masih di bawah usia 19 tahun.

\section{B. Analisis Regresi Logistik Biner}

Pemodelan jenis perceraian dilakukan menggunakan regresi logistik biner dengan kategori respon 0 menunjukkan cerai gugat dan kategori respon 1 menujukkan cerai talak. Pada pemodelan ini, kategori 0 digunakan sebagai pembanding.

Dilakukan dua pemodelan, yakni pembentukan model regresi logistik biner dengan seluruh variabel (Model Awal) dan pembentukan model regresi logistik biner dengan backward elimination (Model Terbaik). Dari dua model tersebut, diperoleh uji kesesuaian masing-masing model sebagai berikut.

Tabel 6

Uji Kesesuaian Masing-masing Mode

\begin{tabular}{cc}
\hline Model & Hosmer-Lemeshow Test \\
\hline Model Awal & 0,002 \\
\hline Model & 0,082 \\
Terbaik & \\
\hline
\end{tabular}

Nilai pada kolom Hosmer-Lemeshow Test merupakan nilai $p$-value hasil pengujian kesesuaian model. Model dianggap sesuai jika memiliki $p$-value lebih dari $\alpha$ yang digunakan yakni 0,05. Berdasarkan hasil uji, model yang dapat dikatakan sesuai yakni Model Terbaik. Uji kesesuaian dari Model Terbaik memberikan hasil bahwa tidak terdapat perbedaan yang signifikan antara hasil pengamatan dengan kemungkinan hasil prediksi model.

Selanjutnya merupakan perhitungan ketepatan klasifikasi menggunakan nilai AUC. Confusion matrix regresi logistik biner hasil seleksi backward atau Model Terbaik disajikan pada Tabel 7.

Tabel 7

Confusion Matrix Regresi Logistik Biner Model Terbaik

\begin{tabular}{ccc}
\hline Observasi & \multicolumn{2}{c}{ Prediksi } \\
\cline { 2 - 3 } & Cerai Gugat & Cerai Talak \\
\hline Cerai Gugat & 2.321 & 185 \\
\hline Cerai Talak & 282 & 703 \\
\hline
\end{tabular}

Tabel 7 menunjukkan hasil klasifikasi jenis perceraian. Selanjutnya dilakukan perhitungan untuk mendapatkan nilai ketetapan klasifikasi berdasarkan nilai AUC, sensitivitas, dan spesifitas seperti berikut.

$$
\begin{gathered}
A U C=\frac{1}{2}\left(\frac{2.321}{2.321+185}+\frac{703}{282+703}\right)=0,82 \\
\text { Sensitivitas }=\frac{2.321}{2.321+185}=0,9 \\
\text { Spesifisitas }=\frac{703}{282+703}=0,7
\end{gathered}
$$

Berdasarkan perhitungan tersebut dapat diketahui bahwa nilai AUC dari hasil pengklasifikasian adalah sebesar $82 \%$, dimana hasil klasifikasi tersebut masuk dalam kategori Good Classification. Nilai sensitivitas yang dihasilkan atau jenis 
perkara yang termasuk jenis cerai gugat dan tepat diklasifikasikan ke dalam kategori cerai gugat adalah sebesar $90 \%$. Sedangkan nilai spesifisitas yang dihasilkan adalah sebesar $70 \%$, nilai tersebut menunjukkan bahwa jenis cerai talak yang diklasifikasikan secara tepat sebagai cerai talak adalah sebesar $70 \%$.

\section{Pembentukan Model Regresi Logistik Biner dengan Backward Elimination (Model Terbaik)}

Ditemukan adanya indikasi multikolinearitas pada variabel-variabel independen dimana variabel pekerjaan pemohon/penggugat memiliki nilai VIF 11,59 atau lebih dari 10. Untuk mengatasi adanya multikolinearitas, salah satu caranya adalah dengan menggunakan backward elimination. Berikut merupakan langkah untuk mengatasi multikolinearitas dengan menggunakan backward elimination.

Iterasi berhenti pada langkah ke-4 dan didapatkan hasil bahwa variabel prediktor yang berpengaruh signifikan terhadap jenis perceraian adalah usia pemohon/penggugat saat menikah $\left(\mathrm{X}_{1}\right)$, usia termohon/tergugat saat menikah $\left(\mathrm{X}_{2}\right)$, pendidikan pemohon/penggugat $\left(\mathrm{X}_{3}\right)$, pekerjaan pemohon/penggugat $\left(\mathrm{X}_{5}\right)$, pekerjaan termohon/tergugat $\left(\mathrm{X}_{6}\right)$, keadaan istri saat jatuh talak $\left(\mathrm{X}_{8}\right)$, dan sebab perceraian $\left(\mathrm{X}_{10}\right)$. Hasil estimasi parameter ditampilkan dalam Tabel 8.

Uji serentak dilakukan untuk mengetahui adanya pengaruh simultan dari tujuh variabel predictor tersebut. Hasil pengujian serentak menunjukkan bahwa nilai likelihood ratio sebesar 1959,695. Nilai tersebut lebih besar dari $\chi_{0,05 ; 19}^{2}$ yakni 30,144. Selain itu, nilai $p$-value yang dihasilkan sebesar 0,000 dimana nilai tersebut lebih kecil dari $\alpha$ yang digunakan yakni 0,05 . Hal ini memberi keputusan tolak $\mathrm{H}_{0}$ yang berarti minimal terdapat satu variabel prediktor memberikan pengaruh yang signifikan terhadap jenis perceraian.

Selanjutnya dilakukan uji parsial untuk mengetahui variabel predictor mana saja yang berpengaruh signifikan terhadap jenis perceraian. Pada pengujian ini, sebuah variabel dinyatakan berpengaruh signifikan apabila $p$-value kurang dari $\alpha$ sebesar 0,05. Berdasarkan Tabel 13, variabel yang berpengaruh signifikan terhadap jenis perceraian adalah usia pemohon/penggugat saat menikah $\left(\mathrm{X}_{1}\right)$, usia termohon/tergugat saat menikah $\left(\mathrm{X}_{2}\right)$, pendidikan pemohon/penggugat $\left(\mathrm{X}_{3}\right)$, pekerjaan pemohon/penggugat $\left(\mathrm{X}_{5}\right)$, pekerjaan termohon/tergugat $\left(\mathrm{X}_{6}\right)$, keadaan istri saat jatuh talak $\left(\mathrm{X}_{8}\right)$, dan sebab perceraian $\left(\mathrm{X}_{10}\right)$.

Model regresi logistik biner yang terbentuk berdasarkan hasil pengujian parameter adalah sebagai berikut sebagai berikut.

$$
\pi(x)=\frac{\exp (g(x))}{1+\exp (g(x))}
$$

$$
\begin{aligned}
g(x)=-4,287+ & 0,124 X_{1}-0,130 X_{2}-0,314 X_{3(1)} \\
& +0,451 X_{3(2)}+0,486 X_{3(3)}+4,782 X_{5(1)} \\
& +4,985 X_{5(2)}+3,439 X_{5(3)}+3,778 X_{5(4)} \\
& +2,425 X_{5(5)}-1,977 X_{6(1)}-3,473 X_{6(2)} \\
& -1,887 X_{6(3)}-2,032 X_{6(4)}-0,218 X_{6(5)} \\
& +1,508 X_{8(1)}+1,114 X_{8(2)}-1,710 X_{10(1)} \\
& -1,895 X_{10(2)}
\end{aligned}
$$

\begin{tabular}{|c|c|c|c|c|}
\hline Variabel & B & Wald & p-value & $\operatorname{Exp}(B)$ \\
\hline$X_{1}$ & 0,124 & 170,524 & $0,000^{*}$ & 1,132 \\
\hline $\mathrm{X}_{2}$ & $-0,130$ & 174,939 & $0,000^{*}$ & 0,878 \\
\hline $\mathrm{X}_{3}$ & & 23,885 & 0,000 & \\
\hline $\mathrm{X}_{3}(1)$ & $-0,314$ & 4,746 & $0,029 *$ & 0,731 \\
\hline $\mathrm{X}_{3}(2)$ & 0,451 & 8,138 & $0,004 *$ & 1,569 \\
\hline $\mathrm{X}_{3}(3)$ & 0,486 & 2,847 & 0,092 & 1,626 \\
\hline $\mathrm{X}_{5}$ & & 228,813 & 0,000 & \\
\hline $\mathrm{X}_{5}(1)$ & 4,782 & 148,723 & $0,000 *$ & 119,295 \\
\hline $\mathrm{X}_{5}(2)$ & 4,985 & 159,708 & $0,000 *$ & 146,197 \\
\hline $\mathrm{X}_{5}(3)$ & 3,439 & 77,660 & $0,000^{*}$ & 31,158 \\
\hline $\mathrm{X}_{5}(4)$ & 3,778 & 95,187 & $0,000 *$ & 43,735 \\
\hline $\mathrm{X}_{5}(5)$ & 2,425 & 25,269 & $0,000^{*}$ & 11,304 \\
\hline $\mathrm{X}_{6}$ & & 416,956 & 0,000 & \\
\hline $\mathrm{X}_{6}(1)$ & $-1,977$ & 172,436 & $0,000^{*}$ & 0,138 \\
\hline $\mathrm{X}_{6}(2)$ & $-3,473$ & 273,914 & $0,000 *$ & 0,031 \\
\hline $\mathrm{X}_{6}(3)$ & $-1,887$ & 97,934 & $0,000^{*}$ & 0,152 \\
\hline $\mathrm{X}_{6}(4)$ & $-2,032$ & 121,267 & $0,000^{*}$ & 0,131 \\
\hline $\mathrm{X}_{6}(5)$ & $-0,218$ & 0,470 & 0,493 & 0,804 \\
\hline $\mathrm{X}_{8}$ & & 87,047 & 0,000 & \\
\hline $\mathrm{X}_{8}(1)$ & 1,508 & 87,010 & $0,000^{*}$ & 4,519 \\
\hline $\mathrm{X}_{8}(2)$ & 1,114 & 1,121 & 0,290 & 3,047 \\
\hline $\mathrm{X}_{10}$ & & 19,991 & 0,000 & \\
\hline $\mathrm{X}_{10}(1)$ & $-1,710$ & 16,837 & $0,000 *$ & 0,181 \\
\hline $\mathrm{X}_{10}(2)$ & $-1,895$ & 3,267 & 0,071 & 0,150 \\
\hline Constant & $-4,287$ & 90,464 & $0,000^{*}$ & 0,014 \\
\hline
\end{tabular}

Tabel 8

Hasil Estimasi Parameter Model 3

*) Signifikan pada $\alpha=5 \%$

Berikut merupakan interpretasi untuk masing-masing nilai odds ratio.

1. Odds ratio $\mathrm{X}_{1}: \boldsymbol{O} \boldsymbol{R}=\boldsymbol{e} \boldsymbol{x p}(\mathbf{1 0} * \mathbf{0}, \mathbf{1 2 4})=\mathbf{3}, 45$. Dengan kenaikan 10 tahun usia pemohon/penggugat, cenderung merupakan cerai gugat (cerai karena permintaan pihak istri) sebesar 3,45 kali dibanding cerai talak.

2. Odds ratio $\mathrm{X}_{2}: \boldsymbol{O} \boldsymbol{R}=\boldsymbol{e} \boldsymbol{x p}(\mathbf{1 0} *-\mathbf{0}, \mathbf{1 3 0})=\mathbf{0}, \mathbf{2 7}$, untuk memudahkan interpretasi maka digunakan $\frac{1}{\mathbf{0 , 2 7}}=$ 3, 7 yang berarti bahwa dengan kenaikan 10 tahun usia termohon/tergugat, cenderung merupakan cerai talak sebesar 4 kali dibanding cerai gugat.

3. Odds ratio $\mathrm{X}_{3(2)}: \boldsymbol{O} \boldsymbol{R}=\boldsymbol{e} \boldsymbol{x p}(0,451)=1,569$. Pihak pengaju cerai atau pemohon/penggugat yang berpendidikan setara SMA cenderung 2 kali lebih besar untuk mengalami cerai gugat (cerai karena permintaan pihak istri) dibandingkan pemohon/penggugat yang berpendidikan setara TK dan SD.

4. Odds ratio $\mathrm{X}_{5(2):} O \boldsymbol{R}=\boldsymbol{e x p}(4,985)=146,197$. Pihak pengaju cerai atau pemohon/penggugat yang bekerja 
sebagai TKI memiliki kecenderungan untuk mengalami cerai gugat 146 kali lebih besar dibandingkan pemohon/penggugat yang tidak bekerja.

5. Odds ratio $\mathrm{X}_{6(2)}: \boldsymbol{O} \boldsymbol{R}=\boldsymbol{e} \boldsymbol{x p}(-3,473)=0,031$, untuk memudahkan interpretasi maka digunakan $\frac{\mathbf{1}}{\mathbf{0 , 0 3 1}}=$ 32, 25. Pihak lawan atau termohon/tergugat yang bekerja sebagai ART memiliki kecenderungan untuk mengalami cerai talak (cerai karena permintaan pihak suami) 32 kali lebih besar dibandingkan termohon/tergugat yang tidak bekerja.

6. Odds ratio $\mathrm{X}_{8(1)}: \boldsymbol{O R}=\boldsymbol{e x p}(\mathbf{1}, \mathbf{5 0 8})=\mathbf{4 , 5 1 9}$. Cerai gugat dengan kondisi istri dalam keadaan suci cenderung 5 kali lebih besar dibandingkan kondisi istri dalam keadaan tidak diketahui.

7. Odds ratio $\mathrm{X}_{10(1)}$ : $\boldsymbol{O} \boldsymbol{R}=\boldsymbol{e} \boldsymbol{x p}(-\mathbf{1}, \mathbf{7 1 0})=\mathbf{0 , 1 8 1}$, untuk memudahkan interpretasi maka digunakan $\frac{1}{\mathbf{0 , 1 8 1}}=\mathbf{5 , 5 2}$. Perceraian yang disebabkan oleh masalah moral pada perceraian dengan jenis cerai talak (cerai karena permintaan suami), cenderung 6 kali lebih besar dibandingkan perceraian akibat meninggalkan kewajiban.

\section{KESIMPULAN DAN SARAN}

\section{A. Kesimpulan}

Berdasarkan analisis yang telah dilakukan, diperoleh beberapa kesimpulan sebagai berikut:

1. Melalui analisis statistika deskriptif diperoleh karakteristik data perceraian bahwa perceraian di Kabupaten Lumajang 71,8\% adalah berupa cerai gugat, sementara sisanya adalah cerai talak. Di Kabupaten Lumajang terdapat kasus pernikahan dini. Pihak istri yang mengajukan cerai cenderung memiliki tingkat pendidikan lebih tinggi dibandingkan suami yang mengajukan cerai. Pihak pemohon/penggugat memiliki tingkat pendidikan lebih tinggi daripada pihak termohon/tergugat. Jumlah perceraian paling tinggi terjadi di Kecamatan Tempeh, Pasirian, Candipuro, Lumajang, dan Randuagung.

2. Variabel yang berpengaruh signifikan terhadap jenis perceraian adalah usia pemohon/penggugat saat menikah $\left(\mathrm{X}_{1}\right)$, usia termohon/tergugat saat menikah $\left(\mathrm{X}_{2}\right)$, pendidikan pemohon/penggugat $\left(\mathrm{X}_{3}\right)$, pekerjaan pemohon/penggugat $\left(\mathrm{X}_{5}\right)$, pekerjaan termohon/tergugat $\left(\mathrm{X}_{6}\right)$, keadaan istri saat jatuh talak $\left(\mathrm{X}_{8}\right)$, dan sebab perceraian $\left(\mathrm{X}_{10}\right)$. Model ini memiliki nilai akurasi AUC sebesar $82 \%$ dimana hasil klasifikasi tersebut masuk dalam kategori Good Classification.

\section{B. Saran}

Berdasarkan penelitian yang telah dilakukan, saran yang dapat diberikan bagi Pengadilan Agama Lumajang maupun Pemerintah Kabupaten Lumajang adalah memperhatikan wilayah-wilayah dengan jumlah perceraian tinggi untuk menekan angka perceraian di Kabupaten Lumajang. Selain itu juga perlunya sosialisasi di Kecamatan Pasirian, Tempeh, Candipuro, dan Randuagung mengenai pernikahan dini karena jumlah pelaku pernikahan dini di daerah-daerah tersebut paling tinggi di Kabupaten Lumajang. Pengadilan Agama Lumajang juga perlu menambah variabel data perkara perceraian seperti tingkat pengeluaran dan sejarah keluarga berkaitan dengan perceraian, karena berdasarkan penelitian, dua variabel tersebut turut berkontribusi mempengaruhi perceraian.

Saran bagi penelitian selanjutnya adalah cara penanganan multikolinearitas yang menggunakan metode lain, salah satunya dengan menggunakan Ridge Regression [8]. Selain itu, dapat juga dilakukan pemetaan kasus perceraian di Kabupaten Lumajang dengan menggunakan Analisis Korespondensi.

\section{DAFTAR PUSTAKA}

[1] R. P. Newman and M. B. Newman, Principles of Psychology, Illinois: The Dorsey Press, 1983.

[2] A. Agresti, Categorical Data Analysis, New Jersey: John Wiley \& Sons, 2002.

[3] D. Gujarati, Basic Econometrics (4th edition), New York: The McGraw-Hill., 2004.

[4] Hosmer and Lemeshow, Applied Logistic Regression, USA: John Wiley \& Sons, 2000.

[5] R. Johnson and D. Wichern, Applied Multivariate Statistical Analysis, New Jersey: Pearson Education, 2007.

[6] J. Huang and C. Ling, "Using AUC and Accuracy in Evaluating Learning Algorithms," Transactions on Knowledge and Data Engineering, vol. 17, no. 3, pp. 299-310, 2005.

[7] G. James, D. Witten, T. Hastie and R. Tibshirani, An Introduction to Statistical Learning with Applications in R, New York: Springer Science+Business Media, 2013.

[8] D. M. Putra and V. Ratnasari, Pemodelan Indeks Pembangunan Manusia (IPM) Provinsi Jawa Timur dengan Menggunakan Regresi Logistik Ridge, Surabaya: Teknologi Sepuluh Nopember, 2015. 